\title{
Analisa Karakteristik Traksi serta Redesign Rasio Transmisi pada Mobil Mitsubishi Strada Triton GLX
}

\author{
Nyoman Angga Adwitya Kirana dan I Nyoman Sutantra \\ Departemen Teknik Mesin, Institut Teknologi Sepuluh Nopember (ITS) \\ Corresponding Author: tantra@me.its.ac.id
}

\begin{tabular}{l} 
ARTIKEL INFO \\
\hline Informasi Artikel \\
Artikel masuk: 6-8-19 \\
Artikel revisi: 26-12-19 \\
Artikel diterima: 26-12-19 \\
\end{tabular}

\section{Kata Kunci}

Karakteristik Traksi, Progressi Geometri, Redesign, 2WD, 4WD

\section{ABSTRAK}

\begin{abstract}
Bandara sam Ratulangi berlokasi di Kota Manado Provinsi Sulawesi Utara. Evaluasi yang dilakukan terhadap ini adalah evaluasi panjang dan lebar runway, evaluasi kawasan keselamatan operasi penerbangan terhadap topografi, dan evaluasi pola pergerakan pesawat terhadap topografi. Selain itu dilakukan juga evaluasi kapasitas dan berat masing-masing pesawat terbang yang beroperasi berkaitan dengan penentuan jarak tempuh optimum pesawat yang digunakan untuk penentuan potensi rute tambahan. Terdapat 4 kesimpulan dalam Studi ini. Pertama, Untuk pesawat kritis Boeing 737 - 900, runway yang tersedia di Bandara Sam Ratulangi Manadomasih memenuhi dimana TORA pesawat Boeing 737 - 900 adalah $2580 \mathrm{~m}$ dan lebar runway dibutuhkan sesuai kriteria pesawat adalah $45 \mathrm{~m}$. Sedangkan panjang runway yang tersedia adalah $2650 \mathrm{~m}$ dengan lebar $45 \mathrm{~m}$. Kedua, untuk evaluasi KKOP terhadap topografi, pada potongan memanjang topografi bandara masih memenuhi batasan KKOP. Sedangkan pada potongan melintangnya, terdapat topografi dimana ketinggiannya melebihi batas KKOP. Ketiga, pola pergerakan pesawat Boeing 737 - 900 tidak mengalami gangguan saat melakukan lift off. Sehingga untuk pola pergerakan pesawat selanjutnya tidak terjadi gangguan keselamatan operasi penerbangan akibat topografi. Sampai saat ini, Pesawat Boeing 737 - 900 beroperasi dengan jarak tempuh paling jauh 1790 nautical miles yaitu dari Bandara Sam Ratulangi Manado menuju Bandara Shanghai Pudong Tiongkok dengan konsumsi bahan bakar sebesar 18475.60 liter. Dari hasil jarak tempuh optimum yang bisa ditempuh pesawat diperoleh untuk jarak tempuh optimum pesawat Boeing 737 - 900 adalah $3544 \mathrm{~km}$ atau 1920 nautical miles dengan konsumsi bahan bakar sebesar 18720 liter.
\end{abstract}

\section{PENDAHULUAN}

Teknologi otomotif mengalami perkembangan pesat beberapa tahun terakhir. Dengan berkembangnya teknologi otomotif maka pengaplikasian penggunaan kendaraan terhadap berbagai medan jalan pun semakin berkembang. Salah satunya ialah penggunaan kendaraan operasional oleh perusahaan-perusahaan tertentu dalam berbagai proyek. Kendaraan operasional yang digunakan harus memiliki kemampuan untuk melewati berbagai medan seperti tanjakan dan jalan berlumpur dengan lancar.

Mitsubishi Strada Triton merupakan salah satu mobil yang paling banyak digunakan oleh perusahaanperusahaan yang bergerak di bidang pertambangan. Menurut PT Krama Yuda Tiga Berlian Motor selaku distributor resmi Mitsubishi Indonesia, penjualan Mitsubishi Strada Triton selama tahun 2014 hingga 2015 mengalami peningkatan sebanyak 50\%. Salah satu penyebab hal ini ialah besarnya kebutuhan perusahaanperusahaan pada bidang pertambangan akan mobil operasional yang memiliki kemampuan untuk melalui berbagai medan.
PT Darma Persada merupakan salah satu unit bisnis yang bergerak di bidang jasa dalam berbagai proyek dengan PT Chevron Pacific Indonesia. Dalam operasionalnya, dibutuhkan kendaraan yang mendukung mobilitas pada berbagai macam bidang, terutama jalan menanjak 30 derajat dan medan berlumpur. Oleh karena itu, diperlukan suatu penelitian terkait analisis kinerja traksi serta redesign terhadap rasio gigi dan transmisi Mitsubishi Strada Triton GLX 2012 untuk meningkatkan performa kendaraan tersebut.

\section{URAIAN PENELITIAN}

Secara umum kinerja kendaraan dapat dibedakan menjadi 3 jenis yaitu kinerja traksi kendaraan, kinerja kestabilan arah kendaraan, dan kinerja pengaman kendaraan. Pada kinerja traksi kendaraan, kemampuan kendaraan untuk melaju serta mengangkut beban pada dasarnya adalah kemampuan kendaraan untuk melawan gaya hambat. Gaya dorong atau kemampuan kendaraan juga sangat dipengaruhi oleh kemampuan mesin kendaraan, pemilihan tingkat dan rasio transmisi, dan jenis transmisi yang dipakai. Pada umumnya, informasi 
mengenai karakteristik traksi sebuah kendaraan ditampilkan dalam sebuah grafik yang menampilan data kecepatan kendaraan, gaya dorong kendaraan pada masing-masing tingkat transmisi, serta gaya hambat kendaraan

\section{A. Gaya Hambat Aerodinamis}

Gaya hambat karena udara pada mobil disebut dengan drag force.

$$
\begin{aligned}
\mathrm{R}_{\mathrm{a}}=\frac{1}{2} \times \rho \times \mathrm{C}_{\mathrm{d}} \times \mathrm{A}_{\mathrm{f}} \times \mathrm{V}_{\mathrm{a}}{ }^{2} \\
\text { dimana, } \mathrm{R}_{\mathrm{a}}=\text { hambatan aerodinamika }(\mathrm{N}) \\
\rho=\text { massa jenis udara }\left(\mathrm{kg} / \mathrm{m}^{3}\right) \\
\mathrm{C}_{\mathrm{d}}=\text { koefisien drag } \\
\mathrm{A}_{\mathrm{f}}=\text { Luas frontal kendaraan }\left(\mathrm{m}^{2}\right) \\
\mathrm{V}_{\mathrm{a}}=\text { kecepatan relatif angin terhadap } \\
\text { kendaraan }(\mathrm{m} / \mathrm{s})
\end{aligned}
$$

\section{B. Gaya Hambat Rolling}

Gaya hambat rolling yaitu gaya hambat yang terjadi pada ban karena disebabkan oleh sifat histeris pada ban karena adanya defleksi dari ban.

$$
\begin{aligned}
& \mathrm{f}_{\mathrm{r}}=\mathrm{f}_{\mathrm{o}}+\mathrm{f}_{\mathrm{s}}\left(\frac{\mathrm{V}_{\mathrm{k}}}{100}\right)^{2,5} \\
& \text { dimana, } \mathrm{f}_{\mathrm{r}}=\text { koefisien hambat rolling }
\end{aligned}
$$

$\mathrm{f}_{\mathrm{o}}$ dan $\mathrm{f}_{\mathrm{s}}=$ koefisien yang nilainya tergantung pada tekanan ban sesuai pada gambar grafik 2.1

$\mathrm{V}_{\mathrm{k}} \quad=$ Kecepatan kendaraan $(\mathrm{km} / \mathrm{h})$

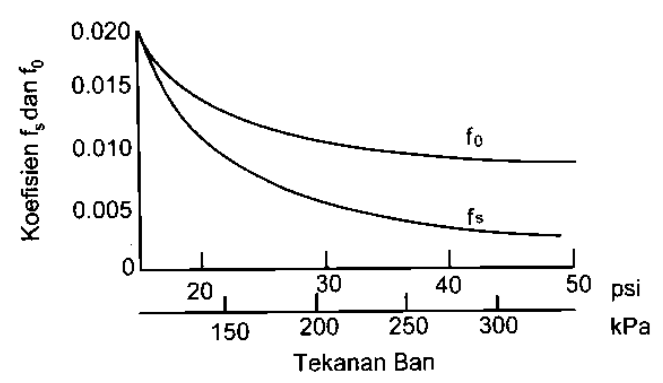

Gambar 1. Grafik pengaruh tekanan ban pada $\mathrm{f}_{\mathrm{o}}$ dan $\mathrm{f}_{\mathrm{s}}$ [1].

Setelah mendapatkan koefisien hambat roling $\left(\mathrm{f}_{\mathrm{r}}\right)$, maka dengan menggunakan rumus berikut besarnya gaya hambat roling dapat dicari dengan menggunakan rumus berikut.

$$
\begin{gathered}
\mathrm{R}_{\mathrm{r}}=\mathrm{f}_{\mathrm{r}} \times \mathrm{W} \\
\text { dimana, } \mathrm{R}_{\mathrm{r}}=\text { gaya hambat rolling }(\mathrm{N}) \\
\mathrm{f}_{\mathrm{r}}=\text { koefisien hambat rolling } \\
\mathrm{W} \quad=\text { berat kendaraan }(\mathrm{N})
\end{gathered}
$$

\section{Gaya Hambat Tanjakan}

Gaya hambat tanjakan, yaitu gaya hambat yang diakibatkan adanya sudut tanjak yang dilewati oleh kendaraan sehingga beban kendaraan akan bertambah akibat gaya gravitasi yang muncul. Besarnya gaya hambat akibat sudut tanjak dapat dihitung dengan rumus berikut.

$$
\mathrm{R}_{\mathrm{g}}=\mathrm{W} \mathrm{x} \sin \theta
$$

$$
\begin{gathered}
\text { Dimana, } \mathrm{R}_{\mathrm{g}}=\text { gaya hambat tanjakan }(\mathrm{N}) \\
\mathrm{W}=\text { berat kendaraan }(\mathrm{N})
\end{gathered}
$$$$
\theta=\text { sudut kemiringan }\left({ }^{0}\right)
$$

\section{Gaya Hambat Total}

Setelah meninjau tiga buah gaya hambat yang bekerja pada kendaraan, maka gaya hambat total pada kendaraan dapat dirumuskan sesuai persamaan dibawah ini.

$$
\begin{aligned}
& \mathrm{F}_{\mathrm{r}}=\mathrm{R}_{\mathrm{a}}+\mathrm{R}_{\mathrm{r}}+\mathrm{R}_{\mathrm{g}} \\
& \text { Dimana, } \mathrm{F}_{\mathrm{r}} \quad \text { = gaya hambat total } \\
& \mathrm{R}_{\mathrm{a}}=\text { gaya hambat angin } \\
& \mathrm{R}_{\mathrm{r}}=\text { gaya hambat rolling } \\
& \mathrm{R}_{\mathrm{g}} \quad=\text { gaya hambat tanjakan }
\end{aligned}
$$

Akan tetapi, pada saat kendaraan dalam posisi menanjak, besarnya sudut tanjak juga akan berpengaruh terhadap besarnya Rolling Resistance kendaraan akibat perbedaan gaya normal pada kendaraan Sehingga rumus gaya dorong kendaraan total sedikit dimodifikasi menjadi seperti berikut.

$$
F_{r}=\frac{1}{2} \rho \cdot C_{d} \cdot A \cdot V^{2}+f_{r} \cdot W \cdot \cos \theta_{\max }+W \cdot \sin \theta_{\max }
$$

\section{E. Gaya Dorong}

Gaya Dorong adalah gaya yang bekerja berlawanan dengan arah gerak gaya hambat kendaraan yang dihasilkan oleh engine kendaraan yang kemudian disalurkan melalui sistem transmisi sehingga akhirnya dapat menggerakan roda. Nilai dari gaya dorong $\left(F_{t}\right)$ dapat dirumuskan sebagai berikut.

$$
F_{t}=\frac{i_{t} \cdot i_{g} \cdot M_{e} \cdot \eta_{t}}{r}
$$

dimana, $\mathrm{F}_{\mathrm{t}} \quad$ = gaya dorong

$\mathrm{M}_{\mathrm{e}}=$ torsi keluaran dari mesin (N.m)

$\mathrm{r} \quad=$ jari-jari roda $(\mathrm{m})$

$\eta_{\mathrm{t}}=$ efisiensi transmisi,

$i_{\mathrm{t}} \quad=$ perbandingan gigi transmisi

$i_{g}=$ perbandingan transmisi pada garden

Lalu kecepatan maksimum kendaran dalam setiap tingkat transmisi $\left(\mathrm{V}_{\mathrm{k}}\right)$ dapat dirumuskan sebagai berikut.

$$
\mathrm{V}_{\mathrm{k}}=\frac{\mathrm{ne}}{\mathrm{i}_{\mathrm{k}} \times \mathrm{i}_{\mathrm{g}}} \times \frac{2 \pi}{60} \times \mathrm{r}
$$

dimana, $\quad \mathrm{V}_{\mathrm{k}}=$ kecepatan pada tingkat $\mathrm{k}(\mathrm{km} / \mathrm{h})$

$$
\mathrm{I}_{\mathrm{k}} \quad=\text { rasio transmisi pada tingkat } \mathrm{k}
$$

$$
\mathrm{I}_{\mathrm{g}}=\text { rasio gardan }
$$

Dan percepatan kendaraan dapat dirumuskan sebagai berikut.

$$
a_{k}=\frac{\left(\mathrm{F}_{\mathrm{t}}-\mathrm{R}_{\mathrm{r}}-\mathrm{R}_{\mathrm{a}}\right)}{\text { massa }}
$$

\section{F. Gaya Dorong Kendaraan 4WD}

Untuk memprediksi besarnya gaya dorong maksimum dapat didukung oleh kontak roda dan jalan, maka gaya normal pada roda depan dan belakang perlu dicari. Dengan mengambil momen dari titik A maka didapat gaya normal (Rf) tanpa menarik beban pada roda depan sebagai berikut.

$$
W f=\frac{W \cdot l_{2} \cdot \cos \theta-R_{a} \cdot h_{a}-h \cdot a \frac{w}{g} \pm W \cdot h \cdot \sin \theta}{L}
$$

Sedangkan mengambil momen dari titik B didapat gaya normal ( $\mathrm{Rr}$ ) tanpa menarik beban pada roda belakang sebagai berikut.

$$
W r=\frac{W \cdot l_{2} \cdot \cos \theta+R_{a} \cdot h_{a}+h \cdot a \frac{w}{g} \pm W \cdot h \cdot \sin \theta}{L}
$$

\section{G. Teori Progesi Geometri}

Salah satu cara untuk mencari perbandingan gigi antara tingkat transmisi terendah dan tertinggi adalah dengan cara progresi geometris. Cara ini umumnya dipakai sebagai langkah iterasi awal. Batas kecepatan operasi dari 
mesin terendah $\left(\mathrm{ne}_{1}\right)$ dan tertinggi $\left(\mathrm{ne}_{2}\right)$ harus ditetapkan terlebih dahulu. Penetapan ini berdasarkan karakteristik torsi dari mesin, batas ini biasa dipilih disekitar torsi maksimum mesin. Konsep dari progresi geometris ditunjukkan pada gambar 2.4, dimana menggambarkan transmisi dengan 4 tingkat kecepatan.

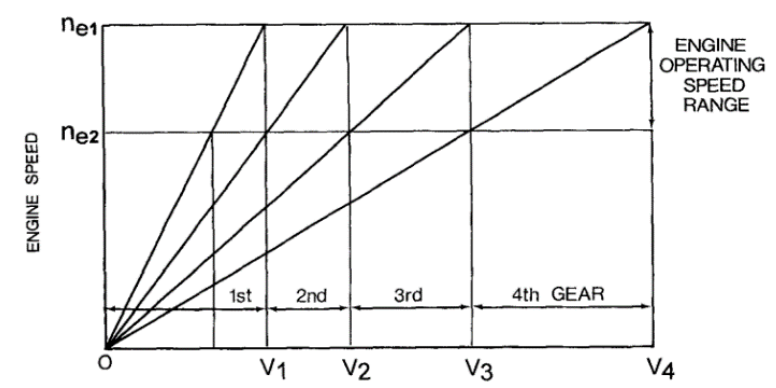

Gambar 2. Grafik pemilihan perbandingan gigi dengan rasio geometri.

Berdasarkan Gambar 2, dengan perbandingan geometris maka untuk transmisi 4 tingkat didapat hubungan perbandingan gigi sebagai berikut.

$$
\frac{\mathrm{i}_{2}}{\mathrm{i}_{1}}=\frac{\mathrm{i}_{3}}{\mathrm{i}_{2}}=\frac{\mathrm{i}_{4}}{\mathrm{i}_{3}}=\frac{\mathrm{ne}_{2}}{\mathrm{ne}_{1}}=\mathrm{K}_{\mathrm{g}}
$$

dimana, $i_{1}, i_{2}, i_{3}, i_{4}=$ perbandingan gigi pada tingkat transmisi I, II, III, IV

$$
\mathrm{K}_{\mathrm{g}}=\text { konstanta perbandingan }
$$

Langkah pertama untuk mendesain tingkat transmisi, harus ditentukan terlebih dahulu rasio transmisi pertama dan rasio transmisi terakhir kendaraan. Untuk menentukan rasio transmisi pertama, dapat dihitung dengan rumus.

$$
\mathrm{i}_{1}=\frac{\mathrm{F}_{1} \cdot \mathrm{r}}{\mathrm{M}_{\mathrm{e}} \cdot \mathrm{C}_{\mathrm{tr}} \cdot \mathrm{i}_{\mathrm{g}} \cdot \mathrm{i}_{\mathrm{tc}} \cdot \eta_{\mathrm{ctr}} \cdot \eta_{\mathrm{tc}} \cdot \eta_{\mathrm{t}}}
$$

Dimana, $F_{1}$ saat kondisi menanjak, besarnya $F_{1}=$ $\mathrm{W} \cdot \operatorname{Sin} \Theta_{\text {maks }}+\mathrm{f}_{\mathrm{r}} \cdot \mathrm{W} \cdot \operatorname{Cos} \Theta_{\text {maks }}+\frac{1}{2} \times \rho \times \mathrm{C}_{\mathrm{d}} \times \mathrm{A}_{\mathrm{f}} \times \mathrm{V}_{\mathrm{a}}{ }^{2}$

Kemudian, rasio transmisi pada tingkat terakhir dirumuskan sebagai berikut.

$$
\mathrm{i}_{\mathrm{n}}=\frac{\mathrm{F}_{n} \cdot \mathrm{r}}{\mathrm{M}_{\mathrm{e}} \cdot \mathrm{C}_{\mathrm{tr}} \cdot \mathrm{i}_{\mathrm{g}} \cdot \mathrm{i}_{\mathrm{tc}} \cdot \eta_{\mathrm{ctr}} \cdot \eta_{\mathrm{tc}} \cdot \eta_{\mathrm{t}}}
$$

Dimana, $F_{n}$ adalah saat kondisi kecepatan maksimum, besarnya $F_{n}=f_{r} \cdot W+\frac{1}{2} \times \rho \times C_{d} \times A_{f} \times V_{a}{ }^{2}$

Selanjutnya, nilai $\mathrm{Kg}$ tersebut digunakan untuk menentukan nilai $\mathrm{i}_{2}, \mathrm{i}_{3}$ dst.

$$
\mathrm{K}_{\mathrm{g}}=\left(\frac{\mathrm{i}_{\mathrm{n}}}{\mathrm{i}_{1}}\right)^{\frac{1}{\mathrm{n}-1}}
$$

\section{H. Tahapan Penelitian}

Pada penelitian ini langkah pertama yang dilakukan adalah melakukan perhitungan gaya hambat dan gaya dorong kendaraan Mitsubishi Strada Triton GLX pada kondisi standar. Setelah itu, dilakukan analisis perhitungan gaya kontak yang terjadi pada 2WD dan 4WD. Lalu terakhir dilakukan evaluasi terhadap grafik karakteristik traksi kendaraan pada kondisi standar, kemudian redesign rasio tiap tingkatan transmisi menggunakan teori progresi geometri sehingga kendaraan memiliki kemampuan tanjak terhadap berbagai medan jalan dan kecepatan maksimum yang lebih baik. Pada penelitian ini akan dilakukan redesign 5, 6, dan 7 tingkat kecepatan dan terakhir akan dilakukan penilaian terhadap hasil redesign pada setiap tingkat kecepatan.

\section{ANALISA DAN PEMBAHASAN}

\section{A. Perhitungan Gaya Hambat Total}

Dengan menggunakan rumus 6 didapatkan grafik gaya hambat total sebagai berikut.

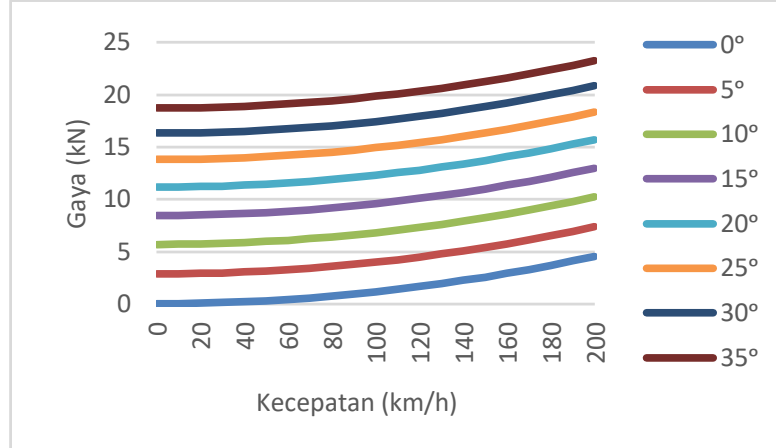

Gambar 3. Grafik gaya hambat total Mitsubishi Strada Triton GLX.

Dari grafik tersebut dapat kita simpulkan bahwa semakin besar kecepatan kendaraan dan tanjakan yang dilewati, maka semakin besar pula gaya hambat yang diterima kendaraan.

\section{B. Perhitungan Gaya Dorong Kendaraan Kondisi Standar}

Dengan menggunakan rumus 7 didapatkan grafik gaya dorong kendaraan sebagai berikut.

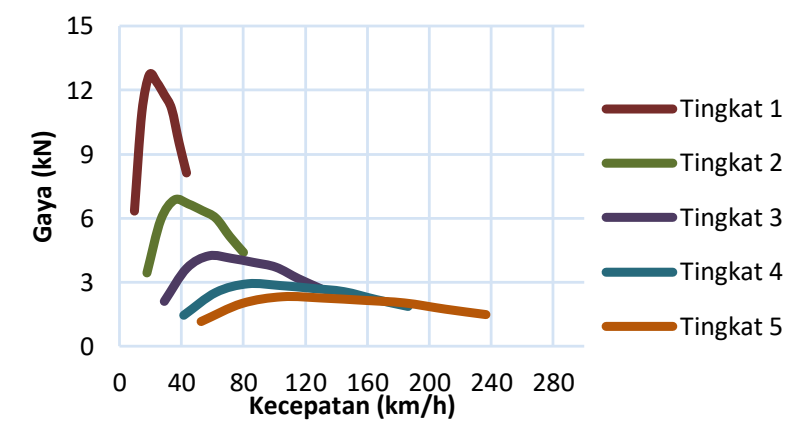

Gambar 4. Grafik gaya dorong Mistubishi Strada Triton GLX kondisi standar

Dari gambar 4 disimpulkan, pada tingkat gigi pertama Mitsubishi Strada Triton GLX dapat mencapai gaya dorong maksimum sebesar $12.35804 \mathrm{kN}$ dan kecepatan sebesar $24.02 \mathrm{~km} / \mathrm{jam}$.

\section{Karakteristik Traksi Kendaraan Kondisi Standar}

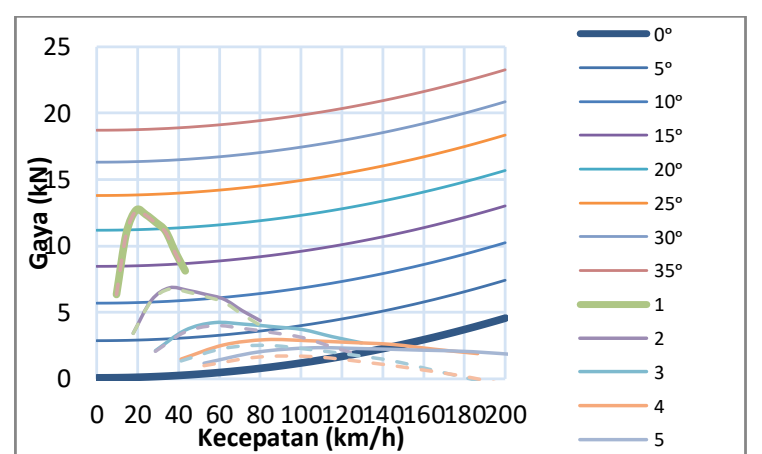

Gambar 5. karakteristik traksi Mitsubishi Strada Triton GLX kondisi standar 
Dari Gambar 5 dapat disimpulkan, bahwa pada tingkat gigi pertama traksi maksimum pada $2000 \mathrm{rpm}$ sebesar $12.707 \mathrm{kN}$ sehingga mobil ini mampu melewati jalanan dengan sudut kemiringan sebesar $20^{\circ}$, kecepatan maksimum yang dapat dicapai oleh Mitsubishi Strada Triton GLX adalah sebesar $145 \mathrm{~km} / \mathrm{jam}$. Selain itu, antara gigi 1 dan 2 pada kecepatan $5 \mathrm{~km} / \mathrm{jam}$ saat perpindahan tingkat gigi pertama menuju tingkat gigi kedua terjadi losses traksi sebesar $6.51 \mathrm{kN}$.

\section{Mode Operasi 4WD}

Transfer case merupakan komponen yang berfungsi untuk membagi daya antara penggerak roda depan dengan penggerak roda belakang. Pembagian daya pada transfer case bisa didapatkan dengan membandingkan antara gaya normal $\left(\mathrm{W}_{\mathrm{f}}\right.$ dan $\left.\mathrm{W}_{\mathrm{r}}\right)$ yang terjadi pada ban depan dan ban belakang seperti pada persamaan 11 dan 12 .

$$
\begin{aligned}
& W_{f}=\frac{32569.2 \times 1.5-103.93 \times 1-0.7 \times 3.29 \times 3320}{3} \\
& W_{f}=13736 \mathrm{~N} \\
& W_{r}=\frac{32569.2 \times 1.5+103.93 \times 1+0.7 \times 3.29 \times 3320}{3} \\
& W_{r}=18834 \mathrm{~N}
\end{aligned}
$$

Selanjutnya pembagian daya dapat dihitung dengan membandingkan gaya normal pada ban depan atau belakang dengan total gaya normal yang terjadi pada kedua ban.

$$
\begin{aligned}
& \eta_{\mathrm{tf}}=\frac{W f}{W r+W f} \\
& =\frac{13736}{18834+13736}=42.1 \% \\
& \eta_{\mathrm{tr}}=\frac{W r}{W r+W f} \\
& =\frac{16696.61}{16696.61+15872.58}=57.9 \%
\end{aligned}
$$

Berdasarkan perhitungan didapatkan bahwa daya yang disalurkan ke ban depan sebesar $42.1 \%$ dan daya yang disalurkan ke ban belakang sebesar $57.9 \%$.

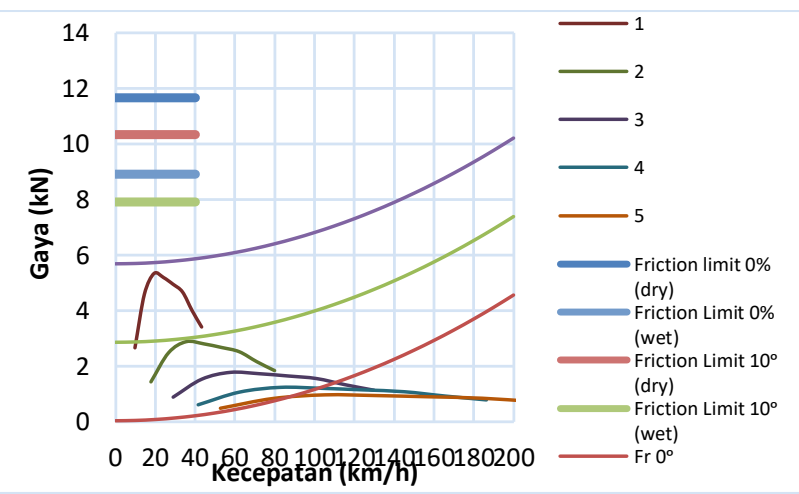

Gambar 6. Karakteristik traksi 4WD (ban depan) pada kondisi jalan aspal.

Gambar 6 menunjukkan bahwa pada gigi 1 traksi yang dihasilkan tidak melewati garis friction limit $0 \%$ untuk kondisi jalan kering maupun basah dan juga pada kondisi jalan kering maupun basah dengan tanjakan sebesar $10^{0}$ hal ini menunjukan bahwa pada kondisi jalan aspal dengan kemiringan $0^{\circ}$ sampai dengan $10^{\circ}$ tidak akan terjadi slip. Tetapi ban depan pada kondisi 4WD tidak mampu melewati tanjakan $10^{\circ}$ hal ini dapat dilihat pada gambar 7 bahwa gigi 1 tidak mampu melewati gaya hambat yang dihasilkan pada jalan dengan kemiringan $10^{\circ}$.

Gambar 7 menunjukan traksi yang dihasilkan pada kondisi jalan aspal dengan pembagian torsi ke ban belakang adalah 57.9\%. Dapat dilihat bahwa pada gigi 1 traksi yang dihasilkan tidak melewati garis friction limit $0^{0}$ hingga $10^{0}$ untuk kondisi jalan kering maupun basah tidak akan terjadi slip. Ban belakang pada kondisi 4WD mampu melewati tanjakan $10^{\circ}$ hal ini dapat dilihat pada gambar 8 bahwa gigi 1 mampu melewati gaya hambat yang dihasilkan pada jalan dengan kemiringan $10^{\circ}$ sehingga pada kondisi 4WD mampu melewati tanjakan sebesar $10^{0}$.

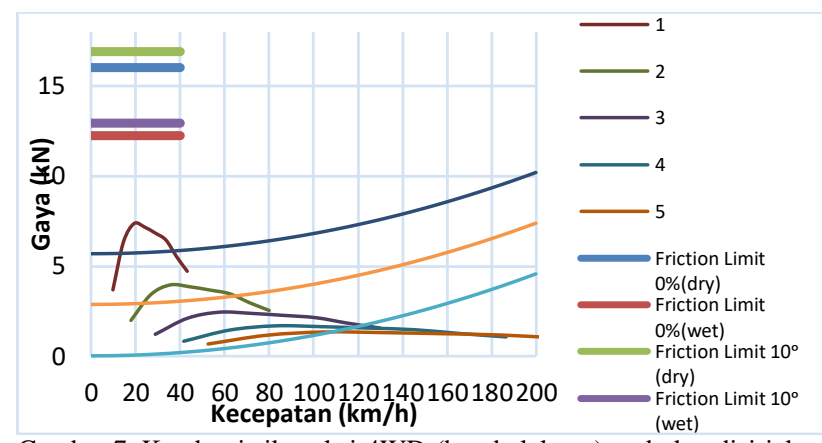

Gambar 7. Karakteristik traksi 4WD (ban belakang) pada kondisi jalan aspal.

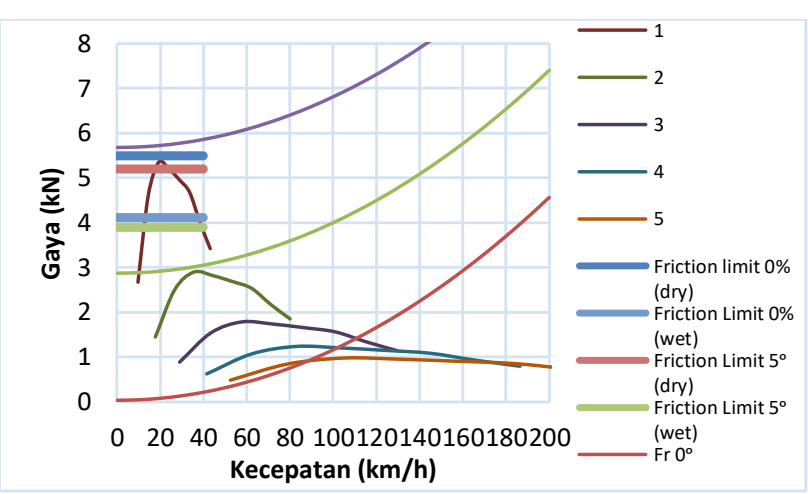

Gambar 8. Karakteristik Traksi 4WD (ban depan) pada Kondisi Jalan Tanah.

Gambar 8 menunjukan traksi yang dihasilkan pada kondisi jalan tanah dengan pembagian torsi ke depan adalah $42.1 \%$. Dapat dilihat bahwa pada gigi 1 traksi yang dihasilkan melewati garis friction limit $0^{0}$ untuk jalan basah dan $5^{0}$ untuk kondisi jalan kering maupun basah. hal ini menunjukan bahwa pada kondisi jalan tanah menggunakan gigi 1 dengan kemiringan $0^{0}$ (basah) sampai dengan $5^{\circ}$ (basah dan tidak basah) akan terjadi slip. Maka pada kondisi jalan bertanah baik basah maupun kering dapat dilewati dengan gigi 2. Tetapi ban depan pada kondisi 4WD hanya mampu melewati tanjakan $0^{\circ}$. Hal ini dapat dilihat pada gambar 11 bahwa gigi 2 tidak mampu melewati gaya hambat yang dihasilkan pada jalan dengan kemiringan $5^{0}$ dan $10^{\circ}$.

Gambar 9 menunjukan traksi yang dihasilkan pada kondisi jalan tanah dengan pembagian torsi ke belakang adalah 57.9\%. Dapat dilihat bahwa pada gigi 1 traksi yang dihasilkan melewati garis friction limit $0^{0}$ dan $5^{0}$ untuk kondisi jalan basah. Hal ini menunjukan bahwa pada kondisi jalan tanah menggunakan gigi 1 dengan kemiringan $0^{0}$ hingga $5^{0}$ pada kondisi jalan basah akan terjadi slip, namun tidak terjadi slip pada kemiringan $0^{0}$ dan $5^{\circ}$ pada kondisi jalan kering. Maka pada kondisi jalan bertanah baik basah maupun kering dapat dilewati dengan menggunakan gigi 2. Ban belakang pada kondisi 4WD menggunakan gigi 2 mampu melewati tanjakan $0^{0}$ dan $5^{9}$ pada jenis jalan kering maupun basah tanpa terjadi slip. 


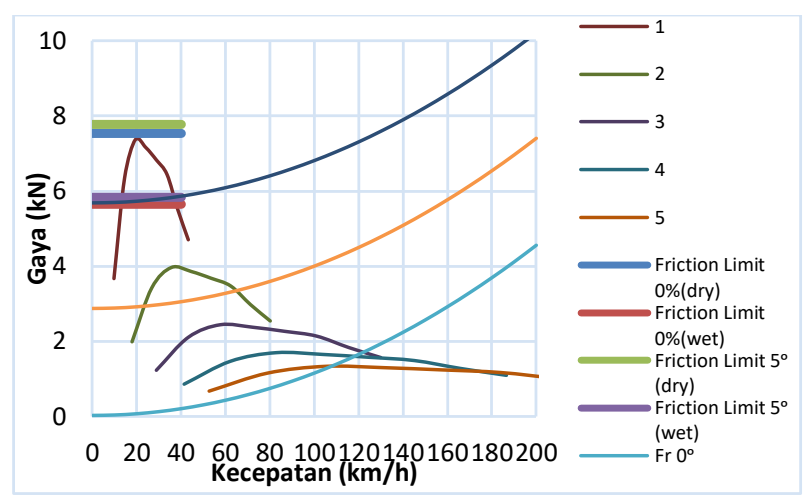

Gambar 9. Karakteristik Traksi 4WD (ban belakang) pada kondisi jalan tanah.

\section{E. Perhitungan Rasio Transmisi Menggunakan Teori Progresi Geometri}

Untuk melakukan perhitungan rasio transmisi yang baru menggunakan teori progresi geometri dibutuhkan informasi daya maksimum yang mampu dihasilkan oleh engine, yaitu $131 \mathrm{~kW}$. Langkah pertama ialah menghitung rasio tingkat gigi pertama, dengan perhitungan sebagai berikut.

$$
\mathrm{i}_{1}=\frac{16683.15 \times 0.406}{400 \times 3.692 \times 0.81}=5.66
$$

Langkah selanjutnya ialah menghitung rasio tingkat gigi akhir dengan perhitungan sebagai berikut.

$$
\mathrm{i}_{\mathrm{n}}=\frac{1321.04 \times 0.406}{400 \times 3.692 \times 0.81}=1.041
$$

Terakhir ialah menentukan tingkatan rasio gigi sebagai berikut

Pada pemasangan 5 tingkat kecepatan

Sehingga,

$$
\mathrm{Kg}=\left(\frac{1.041}{5.66}\right)^{\frac{1}{4}}=0.65
$$

$$
\begin{aligned}
& \mathrm{i}_{2}=0.65 \times 5.66=3.679 \\
& \mathrm{i}_{3}=0.65 \times 3.679=2.391 \\
& \mathrm{i}_{4}=0.65 \times 2.391=1.554
\end{aligned}
$$

Pada pemasangan 6 tingkat kecepatan

Sehingga,

$$
\mathrm{Kg}=\left(\frac{1.041}{5.66}\right)^{\frac{1}{5}}=0.712
$$

$\mathrm{i}_{2}=0.712 \times 5.66=4.029$

$\mathrm{i}_{3}=0.712 \times 4.029=2.868$

$\dot{\mathrm{i}}_{4}=0.602 \times 2.868=2.042$

$\mathrm{i}_{5}=0.602 \times 1.234=1.453$

Pada pemasangan 7 tingkat kecepatan

Sehingga,

$$
\mathrm{Kg}=\left(\frac{1.041}{5.66}\right)^{\frac{1}{6}}=0.754
$$

$\mathrm{i}_{2}=0.754 \times 5.66=4.267$

$\mathrm{i}_{3}=0.754 \times 3.707=3.217$

$\mathrm{i}_{4}=0.754 \times 3.217=2.425$

$\mathrm{i}_{5}=0.754 \times 2.425=1.828$

$\mathrm{i}_{6}=0.754 \times 1.828=1.378$

\section{F. Karakteristik Traksi Hasil Redesign dengan 5 Tingkat Kecepatan}

Pada Gambar 10 terlihat bahwa pada tingkat gigi pertama besarnya traksi maksimum sebesar $16.676 \mathrm{kN}$ pada $2000 \mathrm{rpm}$ sehingga mobil ini mampu melewati jalanan dengan sudut kemiringan sebesar $30^{\circ}$ dan kecepatan maksimum yang dapat dicapai sebesar 146 $\mathrm{km} / \mathrm{jam}$. Dan dari gambar 12, pada kecepatan $25 \mathrm{~km} / \mathrm{jam}$ saat perpindahan tingkat gigi pertama menuju tingkat gigi kedua terjadi loses traksi sebesar $3.94 \mathrm{kN}$.

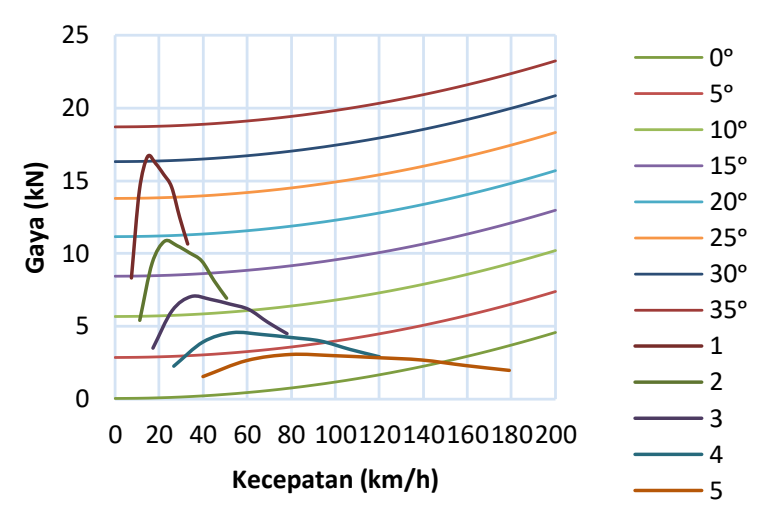

Gambar 10. Karakteristik traksi 5 tingkat kecepatan hasil redesign.

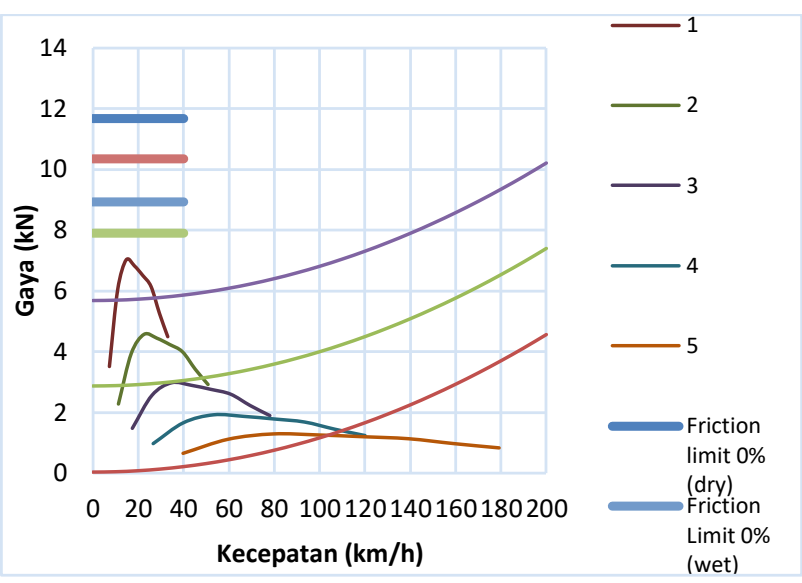

Gambar 11. Karakteristik traksi 4WD (ban depan) pada kondisi jalan aspal 5 tingkat kecepatan setelah redesign

Gambar 11 menunjukan traksi yang dihasilkan pada kondisi jalan aspal dengan pembagian torsi ke depan adalah $42.1 \%$. Traksi maksimum yang dihasilkan gigi 1 sebesar $16.67 \mathrm{kN}$. Setelah redesign ban depan pada kondisi 4WD mampu melewati tanjakan $10^{\circ}$. Dapat dilihat pada gambar 13 gigi 1 mampu melewati gaya hambat yang dihasilkan pada jalan dengan kemiringan $10^{\circ}$ tanpa terjadi slip.

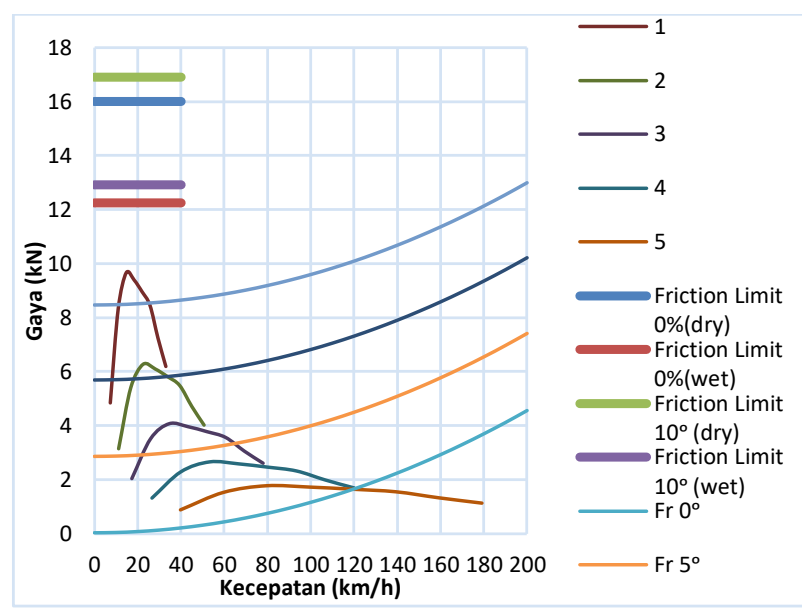

Gambar 12. Karakteristik traksi 4WD (ban belakang) pada kondisi jalan aspal 5 tingkat kecepatan setelah redesign

Gambar 12 menunjukan traksi yang dihasilkan pada kondisi jalan aspal dengan pembagian torsi ke ban belakang adalah 57.9\%. Traksi maksimum yang dihasilkan gigi 1 adalah sebesar $16.67 \mathrm{kN}$. Setelah redesign, ban belakang pada kondisi 4WD mampu melewati tanjakan hingga $15^{\circ}$ hal ini dapat dilihat pada 
grafik 4.15 bahwa gigi 1 mampu melewati gaya hambat yang dihasilkan pada jalan dengan kemiringan $15^{\circ}$.

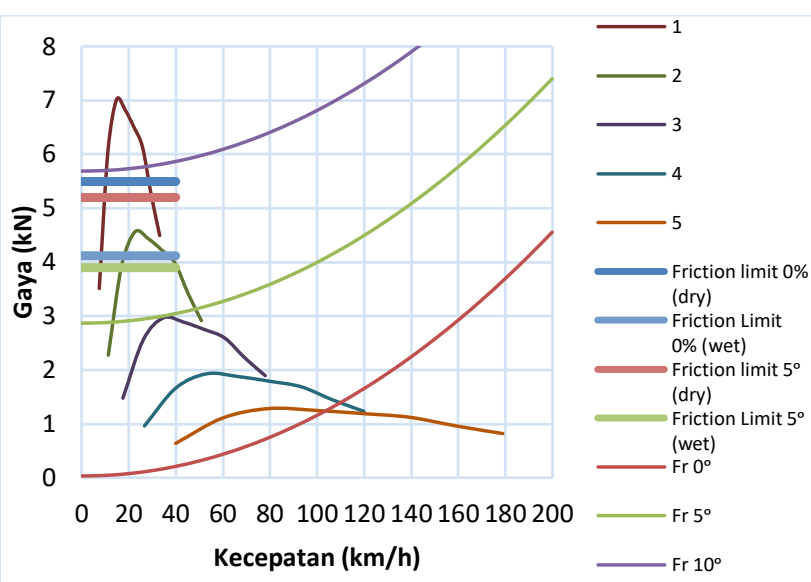

Gambar 13. Karakteristik traksi 4WD (ban depan) pada kondisi jalan tanah 5 tingkat kecepatan setelah redesign.

Gambar 13 menunjukan traksi yang dihasilkan pada kondisi jalan tanah dengan pembagian torsi ke depan adalah $42.1 \%$. Dapat dilihat bahwa pada gigi 1 mampu melewati tanjakan dengan kemiringan $10^{\circ}$ tetapi melewati semua garis adhesion limit, sehingga pada jalan tanah dengan kemiringan $0^{0}$ sampai dengan $5^{0}$ baik kering maupun basah jika dilewati dengan menggunakan gigi 1 maka akan terjadi slip. Dengan menggunakan gigi 2 maka dapat menghindari terjadinya slip pada jalan tanah dengan kondisi kering tetapi pada kondisi basah slip tetap terjadi. Pada saat gigi 2 kendaraan mampu melewati jalan dengan kemiringan $5^{0}$ lebih baik dibandingkan dengan sebelum redesign yaitu kemiringan $0^{\circ}$.
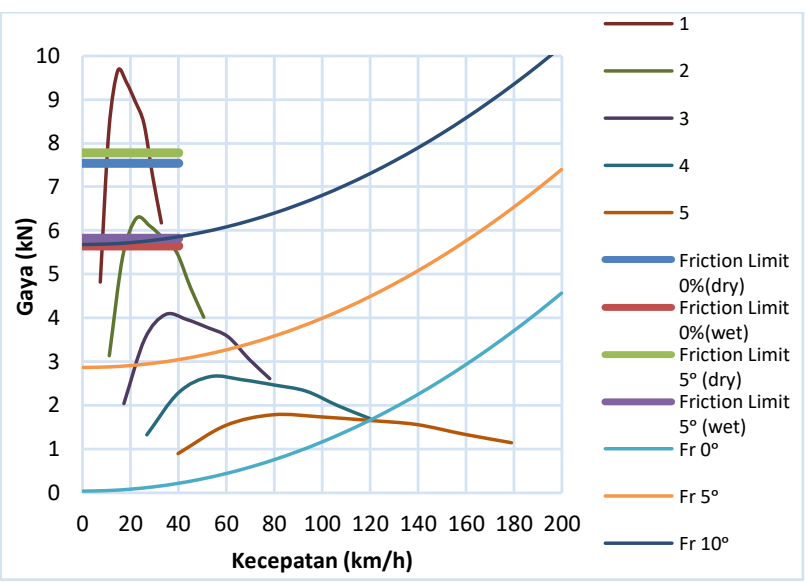

Gambar 14. Karakteristik traksi 4WD (ban belakang) pada kondisi jalan tanah 5 tingkat kecepatan setelah redesign.

Gambar 14 menunjukan traksi yang dihasilkan pada kondisi jalan tanah dengan pembagian torsi ke belakang adalah 57.9\%. Dapat dilihat bahwa pada gigi 1 mampu melewati tanjakan dengan kemiringan $10^{\circ}$ tetapi melewati semua garis adhesion limit, sehingga pada jalan tanah dengan kemiringan $0^{0}$ sampai dengan $5^{0}$ baik kering maupun basah jika dilewati dengan menggunakan gigi 1 maka akan terjadi slip. Jika menggunakan gigi 2 dapat melewati jalan tanah kering tanpa mengalami slip, tetapi slip tetap terjadi jika jalannya basah. Pada saat gigi 2 kendaraan mampu melewati jalan dengan kemiringan hingga $10^{\circ}$.
G. Karakteristik Traksi Hasil Redesign dengan 6 Tingkat Kecepatan

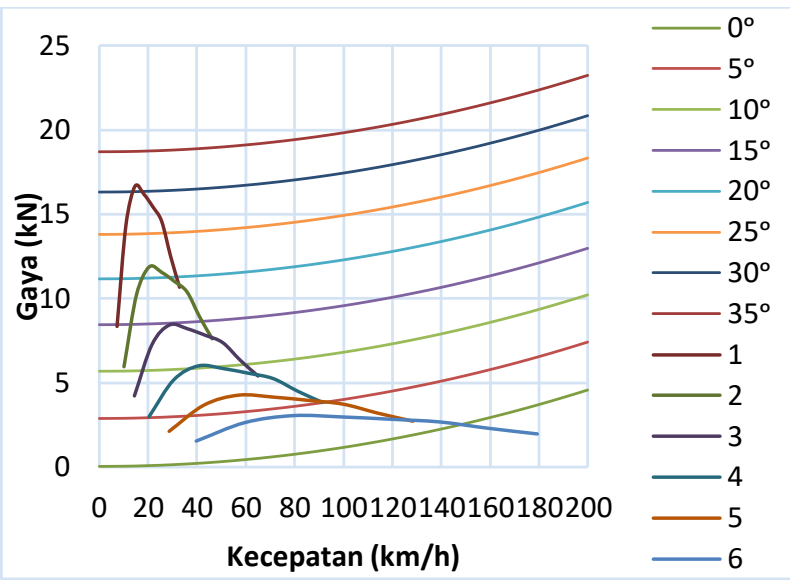

Gambar 15. Karakteristik traksi 6 tingkat kecepatan hasil redesign.

Pada Gambar 15, pada tingkat gigi pertama besarnya traksi maksimum sebesar $16.672 \mathrm{kN}$ pada $2000 \mathrm{rpm}$ sehingga mobil ini mampu melewati jalanan dengan sudut kemiringan sebesar $30^{\circ}$ dan kecepatan maksimum yang dapat dicapai adalah sebesar $146 \mathrm{~km} / \mathrm{jam}$. Dan dari gambar 19, kecepatan $25 \mathrm{~km} / \mathrm{jam}$ saat perpindahan tingkat gigi pertama menuju tingkat gigi kedua terjadi loses traksi $3.05 \mathrm{kN}$. Selain itu, pada kecepatan $40 \mathrm{~km} / \mathrm{jam}$ saat perpindahan tingkat gigi kedua menuju tingkat gigi ketiga terjadi loses traksi sebesar $1.1 \mathrm{kN}$. Namun, bertambahnya sepasang gear akan berpengaruh terhadap dimensi poros pada tranmisi yang menyebabkan perubahan terhadap dimensi transmission case.

\section{H. Karakteristik Traksi Hasil Redesign dengan 7 Tingkat Kecepatan}

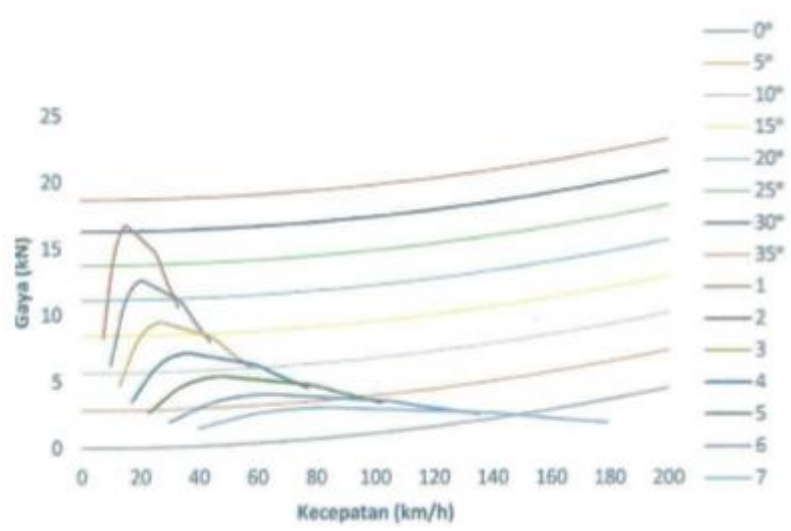

Gambar 16. Karakteristik traksi 7 tingkat kecepatan hasil redesign.

Pada Gambar 16, terlihat bahwa pada tingkat gigi pertama besarnya traksi maksimum sebesar $16.67 \mathrm{kN}$ pada 2000 rpm sehingga mobil ini mampu melewati jalanan dengan sudut kemiringan sebesar $30^{\circ}$ dan kecepatan maksimum yang dapat dicapai sebesar $146 \mathrm{~km} / \mathrm{jam}$. Hasil redesign transmisi dengan 7 tingkat kecepatan menghasilkan distribusi traksi pada range kecepatan 0 $\mathrm{km} / \mathrm{jam}$ sampai dengan $146 \mathrm{~km} / \mathrm{jam}$ yang jauh lebih merata jika dibandingkan dengan karakteristik traksi standar, maupun redesign 5 dan 6 tingkat kecepatan. Hal ini dapat dilihat dari semakin mengecilnya celah antara garis grafik traksi kendaraan saat melakukan perpindahan tingkat kecepatan. Dari gambar 26 dapat disimpulkan bahwa redesign menggunakan 7 tingkat transmisi memiliki nilai losses yang paling kecil. Redesign ini akan berpengaruh terhadap dimensi transmission case 
kendaraan, dimana ukuran poros harus diperpanjang untuk dapat memasang 2 pasang gear tambahan. Oleh karena itu jika ditinjau dari efisiensi konstruksi, redesign dengan menggunakan 7 tingkat transmisi memiliki efisiensi biaya dan efisiensi konstruksi yang paling rendah.

\section{Pemilihan Hasil Redesign untuk Digunakan}

Untuk memilih hasil redesign yang akan digunakan, maka penulis akan memberikan penilaian kepada setiap tingkat transmisi yang diredesign. Penilaian meliputi beberapa faktor. Dan setiap faktor penilaian memiliki bobot yang berbeda. Berikut hasil penilaian yang telah dilakukan.

\begin{tabular}{ccccc}
\multicolumn{5}{c}{ Tabel 2. Penilaian hasil redesign } \\
\hline Faktor & $\begin{array}{r}5 \\
\text { bobot } \\
\text { penilaian }\end{array}$ & $\begin{array}{c}\text { tingkat } \\
\text { kecepatan }\end{array}$ & $\begin{array}{c}6 \\
\text { tingkat } \\
\text { kecepatan }\end{array}$ & $\begin{array}{c}7 \\
\text { tingkat } \\
\text { kecepatan }\end{array}$ \\
\hline $\begin{array}{c}\text { Efisiensi } \\
\text { konstruksi } \\
\text { Distribusi } \\
\text { traksi }\end{array}$ & $40 \%$ & 3 & 2 & 1 \\
$\begin{array}{c}\text { Losses } \\
\text { traksi }\end{array}$ & $15 \%$ & 1 & 2 & 3 \\
$\begin{array}{c}\text { Percepatan } \\
\text { Beban }\end{array}$ & $20 \%$ & 1 & 2 & 3 \\
Total nilai & $10 \%$ & 3 & 1 & 2 \\
\hline
\end{tabular}

Setelah dilakukan penilaian, hasil tertinggi didapatkan oleh transmisi hasil redesign 5 tingkat kecepatan. Transmisi hasil redesign 5 tingkat kecepatan memiliki efisinsi konstruksi yang paling baik dan penambahan beban yang tidak terlalu signifikan walaupun dalam hal distribusi traksi, losses yang dihasilkan pada tingkat kecepatan tertentu, serta percepatan yang dihasilkan masih kurang baik jika dibandingkan transmisi hasil redesign 6 dan 7 tingkat kecepatan.

\section{KESIMPULAN/RINGKASAN}

1. Pada kondisi standar traksi maksimum yang dicapai Mitsubishi Strada Triton GLX 2012 sebesar 12.7075 $\mathrm{kN}$ pada $2000 \mathrm{rpm}$ dengan menggunakan tingkat gigi pertama, tanjakan maksimum yang dapat dilewati adalah tanjakan dengan kemiringan hingga $20^{\circ}$.

2. Pada kondisi standar, mobil mitsubishi strada triton GLX mampu mencapai kecepatan maksimum sebesar $145 \mathrm{~km} / \mathrm{jam}$ pada tingkat gigi keempat. Sedangkan, traksi yang dihasilkan oleh tingkat gigi ke lima dengan gradeability $0 \%$ (kondisi jalan datar) hanya mampu mendorong kendaraan sampai kecepatan maksimum $135 \mathrm{~km} / \mathrm{jam}$ akibat adanya gaya hambat angin dan rolling yang muncul. Sehingga, berdasarkan analisa dapat dikatakan rasio gigi ke lima pada kondisi standar kurang optimal.
3. Pada kondisi standar, ban depan tanpa dibantu oleh ban belakang dengan menggunakan gigi 1 hanya mampu melewati tanjakan sebesar $5^{0}$ dan ban belakang sebesar $10^{\circ}$. Dengan menggunakan gigi 1 slip yang terjadi di ban depan adalah ketika jalan bertanah kondisi basah dengan kemiringan $0^{0}$ hingga $5^{0}$ dan juga kondisi kering pada kemiringan $5^{0}$. Pada ban belakang dengan menggunakan gigi 1 slip yang terjadi di ban depan adalah ketika melewati jalan bertanah kondisi basah dengan kemiringan $0^{0}$ hingga $5^{0}$. Dengan menggunakan gigi 1 slip yang terjadi dapat diatasi dengan menggunakan rpm rendah yaitu 1000 sampai dengan 1300 rpm, atau dengan menggunakan gigi 2.

4. Hasil redesign rasio transmisi pada tingkat gigi pertama (baik pada 5,6 maupun 7 tingkat kecepatan) menghasilkan traksi kotor yang lebih tinggi dari kondisi standar yaitu sebesar $16.6762 \mathrm{kN}$ dengan menggunakan tingkat gigi pertama, tanjakan maksimum yang dapat dilewati adalah tanjakan dengan kemiringan hingga $30^{\circ}$.

5. Hasil redesign rasio transmisi pada tingkat gigi terakhir (baik pada 5,6 maupun 7 tingkat kecepatan) menghasilkan gaya dorong yang mampu melawan gaya hambat angin sampai kecepatan $148 \mathrm{~km} / \mathrm{jam}$.

6. Hasil redesign rasio transmisi (baik pada 5, 6, maupun 7 tingkat kecepatan), ban depan menggunakan gigi 1 tanpa dibantu oleh ban belakang mampu melewati tanjakan hingga $10^{\circ}$ dan ban belakang sebesar $15^{\circ}$. Dengan menggunakan gigi 1 slip terjadi di ban depan ketika melewati jalan bertanah kondisi basah dan kering dengan kemiringan $0^{0}$ hingga $5^{0}$. Pada ban belakang dengan menggunakan gigi 1 slip terjadi ketika melewati jalan bertanah kondisi basah dengan kemiringan $0^{0}$ hingga $5^{0}$. Agar slip tidak terjadi dapat menggunakan gigi 2 dengan menggunakan rpm rendah yaitu dari 1000 sampai dengan $1500 \mathrm{rpm}$.

7. Besarnya loses traksi pada tingkat gigi pertama menuju tingkat gigi kedua ditinjau pada kecepatan 25 $\mathrm{km} / \mathrm{jam}$ mengalami penurunan dari kondisi standar sebesar $6.51 \mathrm{kN}$, hasil redesign 5 tingkat sebesar 3.94 $\mathrm{kN}$, hasil redesign 6 tingkat kecepatan sebesar 3.05 $\mathrm{kN}$, kemudian pada hasil redesign 7 tingkat kecepatan sebesar $2.47 \mathrm{kN}$, begitu pula jika ditinjau pada perpindahan tingkat gigi berikutnya. Artinya loses traksi dapat diminimalisir dengan menambah jumlah tingkatan kecepatan.

\section{DAFTAR PUSTAKA}

[1] I. N. Sutantra and B. Sampurno, Teknologi Otomotif, 2nd ed. Surabaya: Guna Widya, 2010. 